\title{
Space technology meets policy: An overview of Earth Observation sensors for monitoring of cultural landscapes within policy framework for Cultural Heritage
} \author{
Branka Cuca $^{\mathrm{a}, \mathrm{b}, *}$, Diofantos G. Hadjimitsis \\ a Department of Architecture, Built Environment and Construction Engineering, Politecnico di Milano, via Ponzio 31, 20133 Milano, Italy \\ b Department of Civil engineering and Geomatics, Cyprus University of Technology,2-8 Saripolou str., 3036 Limassol, Cyprus
}

\begin{abstract}
A wide range of satellite sensors that provide potentially useful imagery for digital documentation, mapping and monitoring of archaeological sites and cultural landscapes. Although some satellites have stopped acquiring new data, their archived satellite imagery can still be accessed, downloaded and exploited for monitoring of changes and therefore useful for research domain of archaeology and cultural landscapes. The aim of this paper is 1) to make an overview of past and current satellite earth observation optical sensors useful for land monitoring, with focus on cultural landscapes and 2) to illustrate a policy framework that goes beyond recommendations, suggesting the need of valuable information possibly provided by the in satellite imagery. Paper will put focus on Copernicus programme as the most recent mission that provides imagery on the global scale and free of charge. Paper, furthermore, highlights the need for a more structured consideration of the contribution that space technologies services and products can offer to the non-space sectors. The actions for implementation of strategies regarding the currently renewed attention towards cultural heritage protection and management, could soon benefit from the technological achievements of satellite technologies in terms of dedicated operational services and applications, tailored to the needs of end-users such as archaeologists, landscape professionals, public administration, researchers and students.
\end{abstract}

\section{Introduction}

The first legal international instrument that recognises Cultural Landscapes, World Heritage Convention (UNESCO, 1972), defines them as a "combined works of nature and of man". The document emphasises the characteristic of landscape as a container of natural and anthropogenic information deposited in layers over time, and requiring thus exhaustive studies of landscape. Furtherer, the publication "World heritage Landscapes" (ICOMOS-ICSSL, 2009) describes the Cultural landscapes as witnesses of the creative genius, social development and the imaginative and spiritual vitality of humanity, stating that landscapes are "part of our collective identity". Due to their extensive scale, landscapes are particularly appropriate to be observed, studied, monitored (and possibly managed) using integrated geospatial information. More specifically, numerous applications of satellite remote sensing have already largely contributed to study this category of cultural heritage, illustrating both technological potential as well as practical implications for territorial management. Although some satellites have stopped acquiring new data, their archived satellite imagery can still be accessed, downloaded and exploited for monitoring of changes and therefore for research in domain of archaeology and cultural landscapes.

This paper aims to make an overview of the earth observation satellite sensors (both past and currently active) useful for monitoring of cultural landscapes. Recently, several research examples have been provided regarding the overview of scientific work (Agapiou and Lysandrou, 2015), contribution of Space agencies (Giardino, 2011) and the guidelines on the past trends and future tendencies of the discipline (Lasaponara and Masini, 2011). However, yet a limited work can be found on the link between (1) the endorsement of earth observation technologies to support archaeology and culture landscape management within policy frameworks and on (2) the concrete possibilities that such technologies can offer. The paper provides an overview of policies and ongoing global initiatives that already see engagement of satellite Remote Sensing for purposes of heritage management with a special focus on a situation in Europe (section 2), while section 3 illustrates earth observation sensors suitable for archaeological prospection and landscape monitoring in terms of

* Corresponding author at: Department of Architecture, Built Environment and

Construction Engineering, Politecnico di Milano, via Ponzio 31, 20133 Milano, Italy.

E-mail address: branka.cuca@polimi.it (B. Cuca) 
spatial, spectral and temporal resolution. Discussion in section 4 provides food for thought on two main bottlenecks regarding satellite imagery - the data availability and accessibility and the skills required to process such data. Preliminary conclusions and future research recommendations are provided in the section 5.

\section{Satellite Remote Sensing meets heritage: an overview of policies and ongoing initiatives}

\subsection{Some global initiatives}

The link between Space technologies and World Heritage Sites seem to officially exist since 2003 UNESCO and European Space Agency (ESA) have launched an "Open Initiative on the Use of Space Technologies to Support the World Heritage Convention". Further, in 2009 one of the strongest research engines and map providers based on satellite imagery, Google, achieves an agreement with UNESCO on enabling internet users to visit selected World Heritage properties via Google's Street Viewinterface and to browse all other sites on the Google Earth and Google Maps interfaces. In domain of research, a highlight is reach with an International Centre on Space Technologies for Natural and Cultural Heritage being established in Bejing (China) under auspices of UNESCO in 2011. All these initiatives seem to have on one side set the ground for a wide range of novel useful technolo-gical applications; and, on the other, they have indirectly expressed the need for geo-location sites and for up to date geospatial information, that would possibly allow a more efficient and sustainable landscape management.

When it comes to risks evaluation, in 2005 World Heritage Centre has performed a survey among the Member States to access the major threats of climate change and their possible impact to natural and cultural heritage. The climate threats raised for Cultural World Heritage sites were: Hurricane, storms (11 sites); Sea-level rise ( 9 sites); Erosion (both wind and water driven) (8 sites); Flooding (7 sites); Rainfall increase (4 sites); Drought (3 sites); Desertification (2 sites) and Rise in temperature (1 site). Climate change is in fact one of the main factors with a significant impact on changes of cultural heritage and landscapes. A UNESCO report (Colette, 2006), identifies Climate indicators matched to climate change risk and possible impact on heritage. The study further referrers to satellite Remote Sensing as one of the valuable tools, useful for development of "professional monitoring strategies".

More recently, in 2016, the focus in this domain seems to have shifted from consequences on heritage towards the impact of climate change effects on the economic sector that is most commonly linked to heritage - tourism sector. "World Heritage and Tourism in a Changing Climate" reports that in the period of 1979 till 2013 the highest numbers of cases identify as specific factor negatively affecting the outstanding universal value of the property "Management system/management plan". In Europe and North America for example this number accounts for $58 \%$ (Markham et al., 2016). It could be argued that in case of emergency the real threat is the hazardous event itself; in case of ordinary administration the threat seems to be a "hazardous attitude" that leads to inadequate maintenance and thus to a risk of an improper management of cultural heritage sites. Hence it seems in order to propose an overview of existing earth observation satellite sensors that could bring high added value of updated information for monitoring of cultural landscapes and archaeo-landscapes when it comes to monitoring of emergency situation provoked by geo-hazards (e.g. floods, fire, soil erosion or even earthquakes). The objective here is to connect the technological "offer" in terms of services and products with policy "demand" i.e. requirements for a more sustainable manage-ment of territory and its cultural landscape.

\subsection{Current situation in Europe}

Policy makers in Europe seem to be already aware of possibilities that novel technologies can bring to the society and possibly to cultural heritage. Although not referring strictly to satellite remote sensing, European Convention on the Protection of the Archaeological Heritage (Valetta convention) establishes a requirement for "non-destructive methods of investigation" (Council of Europe, 1995), while European Landscape Convention (Florence convention) calls for specific measures aimed at landscape protection, management and planning (Council of Europe, 2000), highlighting that landscape "is not a matter for individual states alone" but "needs to be considered in international policies and programmes". Such approach, that could be interpreted as request for collaboration between disciplines and among states, can be observed as a "shift of scale" and tendency to observe cultural landscapes as a whole also in terms of territorial management and hence sites' protection and maintenance. The link here can be made with INSPIRE Directive (European Parliament, 2007), the first EU legally binding instrument that has set the ground for sharing and re-use of publicly collected geo-spatial information (including products deriving from the satellite imagery). INSPIRE dedicates a specific theme of Annex I to Protected sites, highlighting thus the importance of availability of geospatial data and interoperability of systems even for the management of cultural and natural heritage. In this context, the most recent communication regarding culture "Towards an EU strategy for international cultural relations" (European Commission, 2016) becomes of high relevance to the field of satellite remote sensing: in this document, European Commission states its strong commitment on collaboration with other countries when it comes to protection of cultural heritage. Copernicus Emergency Management Service, has been identified as one that should majorly support this action, provid-ing satellite imagery of cultural heritage sites at risk in order to evaluate damage and plan possible reconstruction. This effort seem to be the first official example and a direct link between an Earth Observation programme (and hence potential services and products deriving from satellite remote sensing technologies) with the domain of monitoring, protection and risk assessment of heritage sites.

Table 1 provides a non-exhaustive list of EU policy recommendations and indications that touch upon the link between cultural heritage at territorial scale (landscapes and archaeological heritage sites) and geo-spatial information, including possibly remote sensing and thus solutions coming from satellite technologies. The first classification was done in terms of direct and indirect reference made in the text of specific policies to the three identified categories: Geospatial informa-tion, Remote sensing and Space technologies. Direct and indirect reference is here intended as use of exact terminology of the three categories in the text. An earlier example of Valetta Convention (1995) does acknowledge the necessity of "non-destructive methods" and "necessity to take note of change", implying the need of remotely sensed information (indirect reference), but it does not make a clear mention to specific technologies to be employed. On the other hand, INSPIRE Directive, explicitly cites (direct reference) all three categories, but with major focus on geospatial boundaries rather than on monitoring of change or risk assessment of the site itself. EU Joint communication (2016) is also a very significant step forward in the domain of satellite remote sensing for archaeology and landscape domains as it expressly recognises the need for an operational service based on satellite imagery, and hence the role of satellite technologies derivatives, when it comes to protection and damage assessment of tangible cultural heritage.

\section{Satellite sensors for monitoring of cultural heritage sites and cultural landscapes}

\subsection{An overview of useful satellite sensors according to period, resolution and data availability}

In the literature there are already several examples that have exploited the potentials of earth observation for monitoring of cultural 

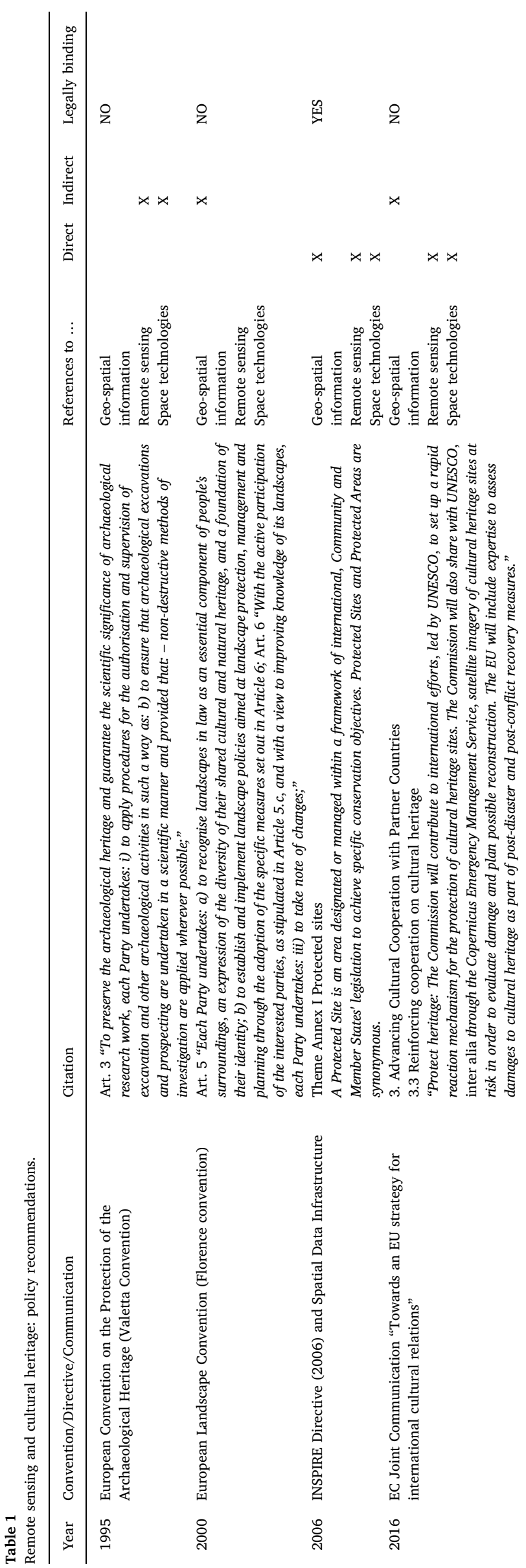

heritage and landscapes, using both radar and optical techniques. Lasaponara and Masini (2013) make an overview on the use of Satellite Synthetic Aperture Radar in Archaeology and Cultural Landscape, identifying some of its advantages such as all-weather imaging tools, night and day operation and low influence by atmospheric effects. Different surfaces and features exhibit different scattering characteristics and, therefore on the basis of the given SAR observation parameters, the backscattering coefficient provides information about surface characteristics, such as roughness, geometric shape and dielectric properties, providing useful inputs for use of SAR in archae-ology domain. Tapete et al. (2015), for example, discuss the use of SAR for monitoring of cultural features threatened by various natural and anthropogenic hazards in Nasca Valley, stating that tracking through time the displacements of landforms and surface changes can add important information for wide-context hazard assessment. Furthermore, SAR methodology can also offer promising perspectives of high resolution SpotLight TerraSAR-X images for feature detection. Such technology can further be used for systematic monitoring of risks affecting the sites and structural deformation assessment caused by geohazards (Cigna et al., 2014). Of particular interest for $\mathrm{CH}$ are the potential SAR applications able to detect and monitor destruction and looting of heritage in areas affected by armed conflicts with no or low possibility for site control on the ground (Tapete et al., 2016).

Optical satellite imagery, on the other side can be used for example for monitoring of crop-marks (Agapiou et al., 2014a), or for risk assessment and mitigation of effects of climate change. It seems however that the most the most well-known mission used for archaeological purposes remains Landsat satellite programme, due to its relative low cost, global coverage and access to archived data since the beginning of its mission in 1972 (Parcak, 2009). The sensors of Landsat satellites were developed in such a way that they are able to recover information in the visible, infrared and thermal part of the spectrum. Furthermore, the sun-synchronous orbit of the Landsat satellite (meaning that the orbit is programmed in such a way for satellite to pass over any given point of the planet's surface at the same local solar time) enables researchers to study many specific areas of interest in a more systematic way. In the period of 1970-today, several new multispectral satellite sensors were launched from different countries, including the USA, Russia (former USSR), France, and Japan. Big interest into the products deriving from these missions have provided a technological push and have contributed to the spatial resolution (size of the pixel on the ground) of the images to be significantly improved. In 1999, the first high-resolution satellite imagery with a spatial resolution of less than $4 \mathrm{~m}$ was available through the IKONOS space programme. The IKONOS satellite was the first one operated by a private organization (called Space Imaging). In 2000, American National Aeronautics and Space Agency (NASA) has demon-strated the first earth observation hyperspectral receiver, called EO-1 Hyperion, with ability to record electromagnetic radiation into 220 different spectral bands. In the decade that followed, additional satellites with higher spatial resolution were launched and their products were made available to the scientific community. In order to provide a better acquaintance of the sensors' characteristics, they were organised in Table 2 (adapted from Hadjimitsis et al., 2013), according to their spatial and spectral properties and frequency of acquisition (temporal resolution). Some relevant publica-tions using data deriving from these sensors have been reported as examples in chronological order.

From Table 3, it can be noticed that most of the missions have multispectral bands of the sensors that cover both the visible and infrared region of the spectrum while some sensors are able to produce thermal images. Many sensors also have the panchromatic band that has a higher spatial resolution that the other bands of the same sensors. More recent missions have instruments of high and very high spatial resolution (even below $1 \mathrm{~m}$ ). However, the imagery produced by such sensors often has pretty reduced swat size (e.g. of several kilometres). It should be further noticed that missions such as Landsat and Sentinel provide data to the users free of charge. These missions might be a reason that increasing number of countries, that do not necessarily have 


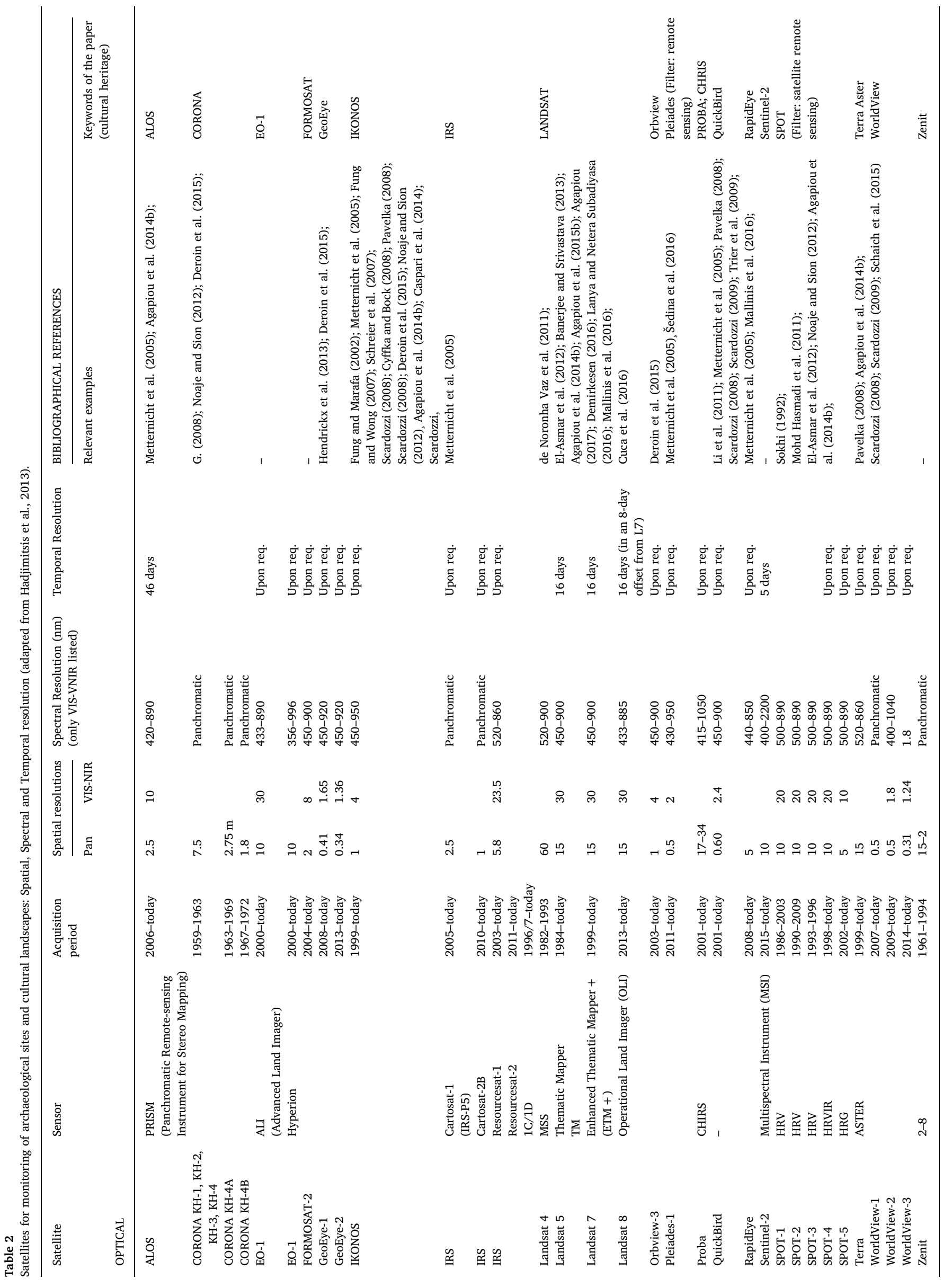


"hardware" space technology production in house, became interested and more actively involved in the use and development of services and products deriving from the space technologies (Agapiou et al., 2015).

Fig. 1 provides an overview of the operational period of the satellites carrying the sensors that are of interest for archaeological prospection, including both the most recent optical solutions such as Sentinel-2 but also those sensors that are no longer active (in grey) due to the fact that archived imagery of such sensors is still a precious resource for research investigation.

\subsection{Copernicus programme and Sentinel satellites}

The paper dedicates a special section to the Copernicus programme, as it is one of the most recent satellite missions that provides imagery globally and free of charge. Furthermore, Copernicus is regarded as EU contribution to GEO and GEOSS; GEOSS - Global Earth Observation System of Systems that fosters the connection and integration of geospatial Open Data (OD) for better monitoring of environment and more informed decision making.

As a successor of Global Monitoring Environment and Security (GMES) Programme, Copernicus is the most ambitious earth observation programme to date. Established in 2014 (EP, 2014), it is composed of the space component i.e. Sentinel satellites (infrastructure coordinated by ESA) and in-situ component i.e. ground stations, airborne and sea-borne sensors and so forth (coordinated by European Environmental Agency and the Member States). Copernicus space component mission consists of a set of satellites organised in six families carrying a range of technologies, such as radar and multi-spectral imaging instruments for land, ocean and atmospheric monitoring. Even before the launch, literature examples have anticipated the possible contribution of Sentinel-2 for example for crop-marks monitoring (Agapiou et al., 2014a). This section gives and overview of currently operational Sentinel-1 (S-1) and Sentinel-2 (S-2) satellites and their sensors.

\subsection{1. $S$-1 radar imagery}

The first Sentinel-1 (S-1) satellite has been launched on a Soyuz rocket from Europe's Spaceport in French Guiana on 3 April 2014. S-1 is a polar-orbiting satellite which means that it passes above or nearly above both poles of the Earth on each revolution, so therefore it has an inclination of closely 90 degrees to the equator. It is an all-weather, dayand-night radar imaging mission for land and ocean services. The main operational mode features a wide swath (coverage) of $250 \mathrm{~km}$ with high geometric and radiometric resolutions. This value is of typically $20 \mathrm{~m}$ Level-1 product resolution. The Sentinel-1 carries a Synthetic Aperture Radar (SAR) instrument that may acquire data in four exclusive modes: 1) Stripmap (SM); 2) Interferometric Wide swath (IW); 2) Extra Wide swath (EW) and 4) Wave (WV).

\subsubsection{S-2 optical imagery}

According to ESA, the Sentinel-2 data was designed to be modified and adapted by users interested in thematic areas such as: spatial planning; agroenvironmental monitoring; water monitoring; forest and vegetation monitoring; land carbon, natural resource monitoring and global crop monitoring. It provides images that can be of significant interest to landscape and archaeo-landscape community, namely optical images in 13 spectral bands with different spatial resolution from the visible and near infrared (VNIR), to the short-wave infrared. Sentinel-2 is a polar-orbiting, multispectral highresolution imaging mission for land monitoring designed to provide optical imagery of vegetation, soil and water cover, inland waterways and coastal areas. S-2 has two components (2A and $2 \mathrm{~B})$ and the first one has been launched in 2014. The data deriving from this satellite are already available and accessible to the large public. They could be of serious potential for built heritage and archaeology community as they regard multi-spectral optical imagery very suitable for both photo-interpretation and for classi-fication and algorithm analysis. In more detail, Sentinel-2provide optical images in 13 spectral bands with different spatial resolution that can be
Table 3

Comparison Sentinel-2 to other or existing satellite missions useful for monitoring of cultural heritage and landscapes.

\begin{tabular}{|c|c|c|c|c|}
\hline & LANDSAT 1-7 & LANDSAT 8 & SPOT & SENTINEL-2 \\
\hline $\begin{array}{l}\text { Mission } \\
\text { lifetime }\end{array}$ & 1972-present & 2013-present & 1986-present & 2015-2025 \\
\hline $\begin{array}{l}\text { Instrument } \\
\text { principle }\end{array}$ & Scanner & Scanner & Pushbroom & Pushbroom \\
\hline $\begin{array}{c}\text { Repeat cycle } \\
\text { (days) }\end{array}$ & 16 & 16 & 26 & $\begin{array}{l}2-3 \\
\text { (with } 2 \\
\text { satellites, every } \\
10 \text { days with } 1 \\
\text { satellite) }\end{array}$ \\
\hline $\begin{array}{l}\text { Swath width } \\
(\mathrm{km})\end{array}$ & 185 & 185 & 60 & 290 \\
\hline Spectral bands & 7 & 11 & 4 & 13 \\
\hline $\begin{array}{l}\text { Spatial } \\
\text { resolution } \\
\text { (meters) }\end{array}$ & $\begin{array}{l}30(\mathrm{~m}) \\
60(\mathrm{~m})\end{array}$ & $\begin{array}{l}15(\mathrm{~m}) ; \\
30(\mathrm{~m}) ; \\
100(\mathrm{~m})\end{array}$ & $\begin{array}{l}2,5(\mathrm{~m}) \\
10(\mathrm{~m}) \\
20(\mathrm{~m})\end{array}$ & $\begin{array}{l}10(\mathrm{~m}) ; \\
20(\mathrm{~m}) ; \\
60(\mathrm{~m})\end{array}$ \\
\hline
\end{tabular}

grouped into:

- 10 m resolution: blue $(490 \mathrm{~nm})$, green $(560 \mathrm{~nm})$, red $(665 \mathrm{~nm})$, and near-infrared (842 $\mathrm{nm})$;

- $20 \mathrm{~m}$ resolution: four bands in the vegetation red-edge spectral domain (705 nm, $740 \mathrm{~nm}, 783 \mathrm{~nm}$ and $865 \mathrm{~nm}$ ) and two large SWIR bands (1610 $\mathrm{nm}$ and $2190 \mathrm{~nm}$ );

- $60 \mathrm{~m}$ resolution: atmospheric corrections and cloud screening (443 nm for aerosol retrieval, $945 \mathrm{~nm}$ for water vapour retrieval and $1375 \mathrm{~nm}$ for cirrus cloud detection).

The pair of Sentinel-2 satellites will have a revisit time which is about 2-3 days at mid latitudes and 5 days at the equator. Their coverage is not limited to land surfaces, but it also extends to the major islands, coastal and inland waters. It has been envisaged that Sentinel-2 enhances continuity of Landsat- and SPOT- like information thanks to the higher revisit frequency and a very large swath $(290 \mathrm{~km} \times 290 \mathrm{~km})$, much larger than currently available Landsat $\mathrm{ETM}+(180 \mathrm{~km} \times 172 \mathrm{~km})$ and SPOT-5 $(60 \mathrm{~km} \times 60 \mathrm{~km})$, see Table 2

Satellite information of Copernicus programme is further interesting and valuable to the research community as it can provide a valuable integration to the American Landsat mission, ensuring a free-of-charge

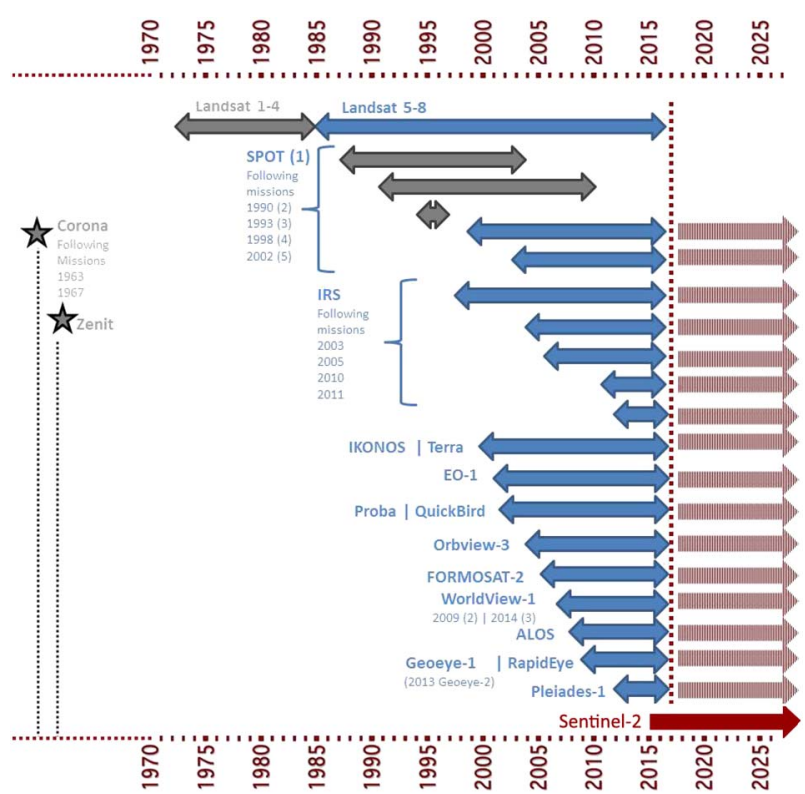

Fig. 1. Satellites for Archaeological prospection and cultural landscape monitoring: Timeline according to image availability. 
coverage of the entire globe in nearly $2-3$ days. The unique combination of S-2 satellites, in integration with other ongoing EO initiatives such Landsat 8 (L8) seems very promising in bringing serious benefits to agriculture and landscape analysis (Cuca et al., 2015). When it comes to the analysis of activities affecting landscape modifications (including the agriculture sector), the requirements usually regard monitoring scales compatible to a ground resolution of few tenths of a meter. Barazzetti et al. (2016) argues that, upon the examination of the bands of $10 \mathrm{~m}$ and $15 \mathrm{~m}$ (namely L8 Band 8 and S-2 band 3), it is expect that a combination of L8 and S-2 data acquired over the same area is able to provide quite robust datasets for this kind of analysis, leading thus towards possible future applications for cultural heritage and landscape that require a more systematic and integrated approach for satellite image processing.

\section{Discussion}

The use, interoperability and sharing geospatial information, including derivatives of satellite imagery, is inserted in such a dynamic policy context with several factors playing an important role. These factors regard specific decision-making frameworks and ongoing international initiatives that largely affect the way in which geospatial information is perceived, used and studied but also the way in which the extracted information can influence current and future decisions regarding some of the main societal challenges. One of the main assets for implementation of such initiatives illustrated in section 2 is data availability and accessibility. The paper has made an emphasis on Copernicus data as a new source of satellite imagery provided on a global scale and available free of charge. Such approach to data distribution recalls the bases of Open Government Data (OGD), a European initiative that seems to be "technology-driven" and promoted by techno-savvy and entrepreneurs (Janssen, 2012). Four main drivers for OGD are identified by Janssen as: (1) Transparency and account-ability; (2) Participatory governance; (3) Innovation and economic growth and (4) Important internal value for public sector itself. In reference to the latter point, Open data in Europe are considered to be crucial in addressing, environmental pressures, energy efficiency issues, land use and climate change, pollution and traffic management and could have an important impact on more informed decision making and policy creation in domains ranging from "decision support system for businesses, location based services and car navigation systems to weather forecasts and other "apps" for our smartphones" (EC, 2011). Benefits of the recent technological achievements for more effective (re) distribution of Open geo-spatial Data has been described by Cuca, 2016.

Going a step further, while the factors such as transparency, accountability and public participation seems to be common to both, Janssen identifies one of the main gaps of OGD as the lack of "intellectual accessibility". Such feature could be defined as a justified fear that without appropriate skills and knowledge citizens will not be able to fully interpret and use of the "vast amounts of datasets thrown at them"; they will be hence incapable to fully access the information that can be obtained by the interpretation of such Open data. In reference to the satellite remote sensing imagery, as illustrated by this paper, the images available have been generated for numerous purposes and can be found in different spatial and spectral resolutions, depending on the sensor characteristics. However, the elaboration of multi-spectral imagery still requires high professional skills in domain of satellite remote sensing analysis and interpretation. In order to overcome such a gap in the future, major coordinated efforts by the international community will be needed in order to include the topics of satellite remote sensing in the curricula of the new generations of experts in land monitoring and territorial management, especially in the cases of emergencies and danger.

\section{Conclusions and future work}

The possibility to visualise and query digital images of the earth surface more freely and more easily by the means of digitally supported portals and engines (e.g. Google, Bing, Safari) seems to have contributed to a better acquaintance with earth observation domain even by non-experts in geomatics or remote sensing techniques. Such context has contributed to shed a new light on products and services deriving from satellite technologies, long perceived as useful mainly to the environmental scientists. Factors that contribute to the risks regarding cultural heritage and landscapes vary from natural to man-caused. The contribution that satellite remote sensing could bring to heritage monitoring, protection and management has already been widely recognised and experimented by the researchers. The aim of this paper was to make an overview of past and current satellite earth observation sensors useful for monitoring of landscapes, with focus Copernicus programme as the most recent mission that provides imagery on the global scale and free of charge. The policy framework that goes beyond recommendations strictly related to heritage and landscape, suggests the need for extracting and sharing the valuable information enclosed in satellite imagery which now seems to be only a "click away". However, satellite remote sensing for monitoring of archaeology and cultural landscapes seems to be still a "niche" domain with occasional fashionable attention. A more structured consideration of the contribution that advancements in satellite remote sensing can offer to the nonspace sectors (including cultural heritage), could have a considerate effect on the economy, fostering the development of novel services, product and applications tailored to the needs of end-users such as archaeologists, landscape professionals, public administration, researchers and students. Establishing of a dedicated operational Copernicus Service for Cultural Heritage, for example, could significantly influence the development of such novel products. However, in order for a real "market uptake" to be pursued, it is important to consider all economic sectors including industry sector, research sector (in both technology and humanities domain), but also higher education sector that is able to provide appropriate training and skill development for new expert profiles. Authors suggest that concrete actions for implementation of national and regional strategies, that build upon the currently renewed attention towards cultural heritage protection and management, could soon truly benefit from the most recent technological achievements of satellite technologies through dedicated services and applications for monitoring of $\mathrm{CH}$ and landscape. Further research will be conducted exploring the most appropriate "data provider-data user" collaboration formulas based of real user needs, that would bridge the gap between the technological "offer" and policy "demand". Further investigation of selected case studies will aim to illustrate concrete benefits for adopting of satellite imagery for practices of cultural and aracheo-landscapes monitoring internationally and in a more systematic manner.

\section{Acknowledgements}

The results of this research activity have been partially funded by the project CLIMA (Cultural Landscape risk Identification, Management and Assessment), through the Joint Programming Initiative for Cultural Heritage (JPI CH) under agreement number KOINA/IKП-HERITAGE PLUS/0314/07. Thanks to the Cyprus Research Promotion Foundation for funding the project.

\section{References}

Agapiou, A., 2017. Remote sensing heritage in a petabyte-scale: satellite data and heritage Earth Engine (C) applications. International Journal of Digital Earth 10 (1), 85-102. http://dx.doi.org/10.1080/17538947.2016.1250829.

Agapiou, A., Lysandrou, V., 2015. Remote sensing archaeology: tracking and mapping evolution in European scientific literature from 1999 to 2015. J. Archaeol. Sci. Rep. 4 (December 2015), 192-200. ISSN 2352-409X. http://dx.doi.org/10.1016/j.jasrep. 2015.09.010.

Agapiou, A., Alexakis, D.D., Sarris, A., Hadjimitsis, D.G., 2014a. Evaluating the potentials of sentinel-2 for archaeological perspective. Remote Sens. 6 (3), 2176-2194.

Agapiou, A., Alexakis, D.D., Hadjimitsis, D.G., 2014b. Evaluation of spectral sensitivity of ALOS, ASTER, IKONOS, LANDSAT and SPOT satellite sensors intended for the 
detection of archaeological crop marks. Int. J. Digital Earth 7 (5), 351-372. http:/ dx.doi.org/10.1080/17538947.2012.674159.

Agapiou, A., Alexakis, D.D., Lysandrou, V., Sarris, A., Cuca, B., Themistocleous, K., Hadjimitsis, D.G., 2015. Impact of urban sprawl to archaeological research: the case study of Paphos area in Cyprus. J. Cult. Herit. 16 (5), 671-680. http://dx.doi.org/10. 1016/j.culher.2014.12.006. (2015b).

Banerjee, R., Srivastava, P.K., 2013. Reconstruction of contested landscape: detecting land cover transformation hosting cultural heritage sites from Central India using remote sensing. Land Use Policy 34, 193-203. http://dx.doi.org/10.1016/j. landusepol.2013.03.005.

Barazzetti, L., Previtali, M., Cuca, B., 2016. Evaluation of registration accuracy between Sentinel-2 and Landsat 8. In: Fourth International Conference on Remote Sensing and Geoinformation of the Environment (RSCy2016), 4-8 April, Paphos, Cyprus, (in press)

Caspari, G., Balz, T., Gang, L., Wang, X., Liao, M., 2014. Application of Hough Forests for the detection of grave mounds in high-resolution satellite imagery. In: International Geoscience and Remote Sensing Symposium (IGARSS), pp. 906-909. art. no. 6946572. http://dx.doi.org/10.1109/IGARSS.2014.6946572.

Cigna, F., Lasaponara, R., Masini, N., Milillo, P., Tapete, D., 2014. Persistent scatterer interferometry processing of COSMO-skymed stripmap HIMAGE time series to depict deformation of the historic centre of Rome, Italy. Remote Sens. 6 (12), 12593-12618. 2014. http://dx.doi.org/10.3390/rs61212593.

Climate change and World Heritage. Report on predicting and managing the impacts of climate change on World Heritage and Strategy to assist States Parties to implement appropriate management responses. In: Colette, A. (Ed.), World Heritage Reports 22 UNESCO, World Heritage Centre.

Council of Europe, 1995. European Convention on the Protection of the Archaeological Heritage (Valetta Convetnion). (Last accessed in July 2016 via https://www.coe.int/ en/web/conventions/full-list/-/conventions/treaty/143)

Council of Europe, 2000. European Landscape Convention (Florence Convention). (https://www.coe.int/en/web/conventions/full-list/-/conventions/treaty/176). Cuca,

B., 2016. Geospatial future is open. Proc. of 16th Int. Conf. on computational science and its applications. In: Murgante, B. (Ed.), Computational Science and Its Applications - ICCSA 2016, 16th Int. Conference, Beijing, China, July 4-7, 2016, Proc. Part III, LNCS 9788. (C) Springer-Verlag, Berlin Heidelberg, pp. 491-502. 2016. http://dx.doi.org/10.1007/978-3-319-42111-7_39.

Cuca, B., Barazzetti, L., Brumana, R., Previtali, M., 2015. An insight into space and remote sensing technologies concerning agriculture and landscape analysis. In: Proc. SPIE 9535, Third International Conference on Remote Sensing and Geoinformation of the Environment (RSCy2015), 95351F 16-19 March, Paphos, Cyprus, http://dx.doi.org/ 10.1117/12.2192738.

Cuca, B., Agapiou, A., Hadjimitsis, D.G., 2016. Observing landscape changes around the nicosia old town center using multi-temporal datasets. In: Ioannides, M. (Ed.), Digital Heritage. Progress in Cultural Heritage: Documentation, Preservation, and Protection. EuroMed 2016. Lecture Notes in Computer Science. Vol. 10058 Springer, Cham.

Cyffka, B., Bock, M., 2008. Degradation of field terraces in the Maltese Islands - reasons, processes and effects. Geogr. Fis. Din. Quat. 31 (2), 119-128.

Demirkesen, A.C., 2016. Flood hazard vulnerability for settlements of Turkey's province of Edirne, using ASTER DEM data and Landsat-7 ETM + image data. Arab. J. Geosci. 9 (3) art. no. 189. http://dx.doi.org/10.1007/s12517-015-2263-z.

Deroin, J.-P., Bou Kheir, R., Abdallah, C., 2015. Geoarchaeological remote sensing survey for cultural heritage management. Case study from Byblos (Jbail, Lebanon). J. Cult. Herit. http://dx.doi.org/10.1016/j.culher.2016.04.014.

El-Asmar, H.M., Ahmed, M.H., Taha, M.M.N., Assal, E.M., 2012. Human Impacts on Geological and Cultural Heritage in the Coastal Zone West of Alexandria to AlAlamein, Egypt. Geoheritage 4 (4), 263-274. http://dx.doi.org/10.1007/s12371 012-0066-0.

European Commission, 2011. Communication from the Commission on open data. In: An Engine for Innovation, Growth and Transparent Governance, ([COM(2011)822] (2011)).

European Commission, 2016. Joint Communication to the European Parliament and the Council "Towards an EU strategy for International Cultural Relations". (last accessed in July 2016 via http://eur-lex.europa.eu/legal-content/EN/TXT/?uri = JOIN $\% 3$ A2016\%3A29\%3AFIN).

European Parliament, 2007. Directive 2007/2/EC of the European Parliament and of the Council of 14 March 2007 Establishing an Infrastructure for Spatial Information in the European Community (INSPIRE). (last accessed in July 2016 via http://eurlex.europa.eu/legal-content/en/ALL/?uri = CELEX:32007L0002).

European Parliament, 2014. Regulation (EU) No 377/2014 of the European Parliamen and of Council of 3April 2014 Establishing the Copernicus Programme and Repealing Regulation (EU) No 911/2010. (last accessed in July 2016 via http:// www.copernicus.eu/sites/default/files/library/ Regulation 377 2014 Copernicus 3April2014.pdf).

Fung, T., Marafa, L.M., 2002. Landscape ecology of feng shui woodlands and the potential for ecotourism using IKONOS images and GIS. In: International Geoscience and Remote Sensing Symposium (IGARSS). Vol. 6. pp. 3246-3248.

Fung, T., Wong, F.K.-K., 2007. Ecotourism planning using multiple criteria evaluation with GIS. Geocarto International 22 (2), 87-105. http://dx.doi.org/10.1080/ 10106040701207332

Giardino, M.J., 2011. A history of NASA remote sensing contributions to archaeology. J. Archaeol. Sci. 38 (9), 2003-2009. September 2011. ISSN 0305-4403. http://dx.doi. org/10.1016/j.jas.2010.09.017.

Hadjimitsis, D. G., Agapiou A., Themistocleous K., Alexakis D. D., Sarris A., (2013): Remote Sensing for Archaeological Applications: Management, Documentation and Monitoring, in Remote Sensing of Environment - Integrated Approaches, Ed. by D. G.
Hadjimitsis, ISBN 978-953-51-1152-8, Publisher: InTech, DOI: http://dx.doi.org/10 $5772 / 3337$

Hendrickx, M., De Laet, V., Stal, C., De Wulf, A., Goossens, R., April 2013. The use of high resolution digital surface models for change detection and viewshed analysis in the urban area around the pyramids of Giza, Egypt. In: Joint Urban Remote Sensing Event 2013, JURSE 2013 2013, Pages 21-24 2013 Sao Paulo; Brazil, pp. 21-23.

ICOMOS-ICSSL, 2009. World heritage Landscapes. UNESCO-ICOMOS Documentation Centre ([http://www.icomos.org/landscapes/Declarados\%20PM\%20y\%20bibliograf \%EDa.pdf, last accessed Dec 13, 2012])

Janssen, K., 2012. Open government data and right to information: opportunities and obstacles. The Journal of Community Informatics 8 (2).

Lanya, I., Netera Subadiyasa, N., 2016. Role of remote sensing and geographyc information system mapping for protected areas land rice field Subak, buffer zones, and area conversion (case studies in Gianyar Regency, Bali Province). IOP Conference Series: Earth and Environmental Science 47 (1) art. no. 012037. http://dx.doi.org/ 10.1088/1755-1315/47/1/012037.

Lasaponara, R., Masini, N., 2011. Satellite remote sensing in archaeology: past, present and future perspectives. J. Archaeol. Sci. 38 (9, September 2011), 1995-2002. ISSN 0305-4403. http://dx.doi.org/10.1016/j.jas.2011.02.002.

Lasaponara, R., Masini, N., 2013. Satellite synthetic aperture radar in archaeology and cultural landscape: an overview. Archaeol. Prospect. 20, 71-78. Online in Wiley Online Library. http://dx.doi.org/10.1002/arp.1452.

Li, Y., Liu, H., Zheng, N., Cao, X., 2011. A functional classification method for examining landscape pattern of urban wetland park: a case study on Xixi Wetland Park, China

Acta Ecol. Sin. 31 (4), 1021-1028.

Mallinis, G., Mitsopoulos, I., Beltran, E., Goldammer, J.G., 2016. Assessing wildfire risk in cultural heritage properties using high spatial and temporal resolution satellite imagery and spatially explicit fire simulations: the case of Holy Mount Athos, Greece. Forests 7 (2) art. no. 46. http://dx.doi.org/10.3390/f7020046.

Markham, A., Osipova, E., Lafrenz Samuels, K., Caldas, A., 2016. World heritage and tourism in a changing climate. In: United Nations Environment Programme, Nairobi, Kenya and United Nations Educational, Scientific and Cultural Organization, Paris, France, . last accessed in July 2016 via http://whc.unesco.org/document/139944.

Metternicht, G., Hurni, L., Gogu, R., 2005. Remote sensing of landslides: an analysis of the potential contribution to geo-spatial systems for hazard assessment in mountainous environments. Remote Sens. Environ. 98 (2-3), 284-303. http://dx.doi.org/10.1016/ j.rse.2005.08.004.

Mohd Hasmadi, I., Pakhriazad, H.Z., Norlida, K., 2011. Remote sensing for mapping RAMSAR heritage site at Sungai Pulai mangrove forest reserve, Johor, Malaysia

Sains Malaysiana 40 (2), 83-88.

Noaje, I., Sion, I. Gr, 2012. Environmental changes analysis in Bucharest City using Corona, SPOT HRV and IKONOS images. Int. Arch. Photogramm. Remote. Sens. Spat. Inf. Sci. 39, 329-334.

de Noronha Vaz, E., Caetano, M., Nijkamp, P., 2011. Trapped between antiquity and urbanism - a multi-criteria assessment model of the greater Cairo Metropolitan area. Journal of Land Use Science 6 (4), 283-299. http://dx.doi.org/10.1080/1747423X. 2010.519059.

Parcak, S.H., 2009. Satellite Remote Sensing for Archaeology. Routledge Taylor and Francis Group press, London and New York.

Pavelka, K., 2008. Using of remote sensing and photogrammetry for documentation of geoglyphs in Nazca/Peru region. In: 29th Asian Conference on Remote Sensing 2008,

ACRS 2008. Vol. 2. pp. 1339-1344.

Scardozzi, G., 2008. Old high resolution satellite images for landscape archaeology: Case studies from Turkey and Iraq. Proceedings of SPIE - The International Society for Optical Engineering 7110 art. no. 711004. http://dx.doi.org/10.1117/12.799997.

Scardozzi, G., 2009. The contribution of high resolution satellite images to the production of base-maps and cartographies for archaeological research in Turkey and Iraq. Proc. SPIE Int. Soc. Opt. Eng. 7478 art. no. 74780B. http://dx.doi.org/10.1117/12.830237.

Schaich, H., Kizos, T., Schneider, S., Plieninger, T., 2015. Land Change in Eastern Mediterranean Wood-Pasture Landscapes: The case of deciduous oak woodlands in Lesvos (Greece). Environ. Manag. 56 (1), 110-126. http://dx.doi.org/10.1007/ s00267-015-0496-y.

Schreier, G., Hernandez, M., Van Ess, M., 2007. Analysis of archaeological sites using remote sensing imagery. In: Proceedings, 32nd International Symposium on Remote Sensing of Environment: Sustainable Development Through Global Earth Observations, (4 p).

Šedina, J., Pavelka, K., Housarová, E., 2016. Archaeological documentation of a defunct Iraqi Town. In: International Archives of the Photogrammetry, Remote Sensing and Spatial Information Sciences - ISPRS Archives, 2016-January, pp. 1031-1035. http:// dx.doi.org/10.5194/isprsarchives-XLI-B1-1031-2016.

Sokhi, B.S., 1992. Spotting historical monuments and sites from 'SPOT' image. J. Indian Soc. Remote Sens. 20 (2-3), 65-71. http://dx.doi.org/10.1007/BF02999202.

Tapete, D., Cigna, F., Lasaponara, R., Masini, N., 2015. Multi-scale detection of changing cultural landscapes in Nasca (Peru) through envisat asar and terrasar-X. In: Engineering Geology for Society and Territory - Volume 8: Preservation of Cultural Heritage. Springer International Publishing, pp. 339-343. http://dx.doi.org/10. 1007/978-3-319-09408-359.

Tapete, D., Cigna, F., Donoghue, D.N.M., 2016. 'Looting marks' in space-borne SAR imagery: Measuring rates of archaeological looting in Apamea (Syria) with TerraSAR X Staring Spotlight (2016). Remote Sens. Environ. 178 (1 June 2016), 42-58. ISSN 0034-4257. http://dx.doi.org/10.1016/j.rse.2016.02.055.

Trier, Ø.D., Larsen, S.Ø., Solberg, R., 2009. Automatic detection of circular structures in high-resolution satellite images of agricultural land. Archaeol. Prospect. 16 (1), 1-15. http://dx.doi.org/10.1002/arp.339.

UNESCO (1972). The world heritage convention at: http://whc.unesco.org/en/ conventiontext/[last accessed 31 Jan 2017]. 